\title{
TOURISM, EDUCATION AND WOMEN'S EMPOWERMENT. THE CASE OF THE WOMEN WEAVERS OF CHINCHERO (CUSCO, PERU)
}

\author{
Cristian Terry \\ Université de Lausanne, Laboratoire d'études des sciences \\ et des techniques (STSLab), Switzerland \\ cristian.terry@graduateinstitute.ch
}

\begin{abstract}
This article studies the relationship between tourism, education, and women's empowerment through ethnographic research in the rural town of Chinchero (Cusco, Peru). The participant observation and interviews with Quechua-speaking women weavers working in textile centers show the importance of tourism as an economic resource and educational resource for them and their children. Beyond the investment in education through tourism income, it is argued that interaction with tourists offers weavers a platform to acquire, practice, and improve their language (English and Spanish) and public speaking skills. This second little-studied aspect allows us to understand how economic and educational elements favor female empowerment in the rural Andes, taking into account its possibilities and limitations.
\end{abstract}

KeYwords: tourism, education, women's empowerment, ethnography, Peru.

TURISMO, EDUCACIÓN Y EMPODERAMIENTO FEMENINO.
EL CASO DE LAS TEJEDORAS DE CHINCHERO (CUSCO, PERÚ)

\section{RESUMEN}

Este artículo estudia la relación entre turismo, educación y empoderamiento de la mujer a través de una investigación etnográfica en el pueblo rural de Chinchero (Cusco, Perú). La observación participante y las entrevistas con tejedoras quechuahablantes que trabajan en centros textiles muestran la importancia del turismo como recurso económico y educativo para ellas y sus hijos. Más allá de la inversión en la educación a través de los ingresos del turismo, se argumenta que la interacción con los turistas ofrece a las tejedoras una plataforma para adquirir, practicar y mejorar habilidades lingüísticas (inglés y español) y de oratoria. Este segundo aspecto, poco estudiado, nos permite comprender cómo elementos económicos y educativos favorecen el empoderamiento femenino en los Andes rurales, tomando en cuenta sus posibilidades y limitaciones.

Palabras Clave: turismo, educación, empoderamiento femenino, etnografía, Perú.

DOI: https://doi.org/10.25145/j.atlantid.2021.12.07

Revista Atlántida, 12; diciembre 2021, pp. 131-157; ISSN: e-2530-853X 


\section{INTRODUCTION}

In the Andean region of Cusco, textile activity has become profitable work in recent years, at least from the point of view of many comuneros and comuneras. ${ }^{1}$ Numerous weavers' associations have been born via promotion of the Peruvian State and NGOs, among other institutions. For example, during my fieldwork in 2014, I met an association of women weavers ${ }^{2}$ from the Umasbamba community that obtained funding from the rural development project "Corredor Puno-Cusco." I was also able to observe other weavers' ventures, supported by the crafts department of the Regional Directorate of Foreign Trade and Tourism of Cusco (DIRCETUR-CUS$(\mathrm{CO})^{3}$, to market their textiles in luxury hotels. In 2012, working as a coordinator for the Potato Park ${ }^{4}$ agro-ecotourism program, I collaborated with Nawpa Away, an association of weavers in the Potato Park supported by the Peruvian NGO ANDES (an acronym for Asociación para la Naturaleza y el Desarrollo Sostenible). That year, Nawpa Away participated in the "Programa Conjunto-Industrias Creativas Inclusivas," funded by the United Nations Development Program (UNDP) and in collaboration with other UN entities. These examples highlight the growing importance of the textile activity in Cusco, mainly linked to the tourism market (see the importance of tourism in the Andes in Baud et al., 2006; Ypeij and Zoomers, 2006).

I would like to continue with a story taken from my fieldwork in the town of Chinchero (about 30 kilometers from Cusco city), the place I will focus this paper on. This story will allow me to ethnographically illustrate the purpose of the present article, providing elements that will be developed throughout it. This story occurred on October 22nd, 2014, in one of the textile centers (centros textiles) of Chinchero. It is worth noting that one of Chinchero's tourist attractions are its textile centers. Visitors almost inevitably pass through these to access other of the town's attractions: the colonial church and the Inca archaeological site. In textile centers, the manual textile activity is explained pedagogically, stage by stage:

"Good morning amigo [friend]," I'm greeted by a young woman in English inviting me to come and sit on a wooden bench. I sit there with four other Brazilian and two German tourists. In front of us are three comuneras dressed in their trajes típicos, their "traditional dress" (Photos 1-2; see also Terry, 2020a). Margarita, the youngest in her twenties, begins to explain to us, stage by stage, the tex-

${ }^{1}$ Qualifier used in Peru to designate the original people of Andean communities.

2 I use the category "weavers" repeatedly. Although many produce weavings for sale, this category also includes that of "sellers." These two categories are not exclusive and vary in degree (some are resellers more than producers for the tourism market). Therefore, it would be more appropriate to perceive these weavers as weavers-sellers.

${ }^{3}$ Dirección Regional de Comercio Exterior y Turismo de Cusco.

${ }^{4}$ Located one hour from Cusco city, the Potato Park is made up of five Andean communities in the Pisac district: Amaru, Chawaytire, Pampallaqta, Paru-Paru and Sacaca. The Potato Park is considered a conservation area of the "Indigenous Bio-cultural Heritage" where native potatoes are mainly preserved (more than a thousand varieties). For more details, see Terry $(2011,2017)$. 


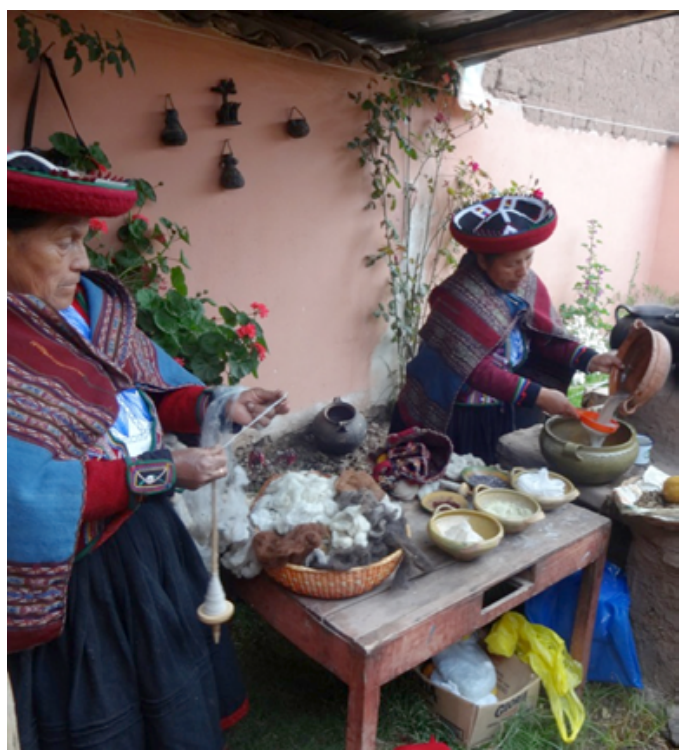

Photo 1. Textile demonstration at Rosa's house during the visit of French tourists.

Dressed in her trajes tipicos, Rosa (located at the extreme right) shows wool washing with the saktana, while her mother (extreme left) spins in a puska or distaff. Photography: C. Terry. October 2014.

tile work process: from shearing (obtaining wool from sheep or alpaca) to weaving, passing through spinning and wool dyeing with cochineal (Dactylopius coccus) and local plants, among other intermediate stages. The explanation of the textile process culminates with weaving, describing textiles techniques and the iconography. The explanation takes place while other colleagues of hers weave on the backstrap loom (manual technology used in Chinchero to weave garments such as ponchos, lliqllas (blankets), scarves, etc.). All explanations are given first in Spanish and then in English, with a good accent and fluency in both languages. Among them, women weavers exchange phrases in Quechua, their mother tongue, especially to coordinate the development of the "textile demonstration" (demostración textil), as the explanation of the entire textile process is commonly called in Chinchero and other parts of the Cusco region.

Margarita is surprisingly fluent in English, allowing her to slip some jokes to the audience: "Here is the saktana, "Inca shampoo." Very good to prevent hair loss. It's a bit late for you sir," she ends her sentence by referring to one of the tourists and laughing with the rest of the visitors. Minutes later, she asks the audience by showing them a bone: "Do you know what it is?" From my research on Andean textiles, I knew that it was ruki, a tool used to separate the threads before sliding the weft and continuing to weave. However, the answer surprises me: "It is the bone of a tourist who did not buy anything." 




Photo 2. Another example of a textile demonstration in one of the textile centers in Chinchero.

Wearing her traje típico like her colleagues, the young weaver explains weaving techniques and local iconography in Spanish and English, next to a backstrap loom. We can observe in the background, behind the weavers who spin, the sales stands.

Photography: C. Terry. May 2017.

After about twenty minutes, the textile demonstration ends. Margarita gives way to the questions of the spectators, who on this occasion came alone, but frequently arrive in a group and in the company of guides from different tour operators. Without further questions, women weavers quickly move to the selling stands, located a few meters from where the demonstration took place (Photo 2). Tourists buy something, even little stuff. I know that sometimes they do it out of commitment because the explanations are free and what these women earn depends on the sales.

Previous works to this paper highlight the economic importance of the textile activity for the tourism market, not only for the weavers of Chinchero (e.g. Gonzales Salazar, 2017; Ypeij, 2012) but more widely in the Cusco region (for Pisac, see Henrici, 2002), in the Peruvian Andes (for Taquile, see Zorn, 2004) and in other Andean countries (Ariel de Vidas, 1996). The joke of the bone of the tourist who did not want to buy anything highlights the commercial and economic interest behind free textile demonstrations. Women's charisma and funny tone during the explanations favor the sales at the end of these demonstrations. For its part, the rural town of Chinchero is part of the Sacred Valley tourist circuit, one of the most frequented by tourists, probably after Machu Picchu. It is also worth mentioning the tourist promotion of Chinchero by the State, guides and tour operators that 
promote tourism in this area, which increases the income generated. The opening hours that go, roughly, from 9 a.m. to 8 p.m. (coinciding with the arrival and departure of tourists) provide ample working hours range to generate income every day of the week, throughout the year.

Without undermining the importance of the extensively studied economic aspects, this paper suggests looking beyond these aspects. The story I told before allows me to make the following argument: tourism becomes today a platform for women's education and empowerment in the Peruvian Andes, mainly in Chinchero. The term "empowerment," used many times by the community members themselves (Terry, 2019), is widely spread among NGOs and international institutions (a concept used, for example, by the Programa Conjuntos) and even in academic works (cf. Asensio, 2016; Pérez Galán and Fuller, 2015). I will hereby use the concept of "women's empowerment" (empoderamiento femenino) taken from Raúl Asensio (2016, p. 345). The concept refers to "a complex and multidimensional process that emphasizes the individual and collective dimensions of power" (Calvès, 2009, p. 744). Empowerment helps people "develop their capabilities, have a sense of control over their wellbeing and lead dignified lives" (Scheyvens and Russell, 2012, p. 422). The concept entails psychological, social, economic, political aspects, among others (Abou-Shouk, 2020; Scheyvens, 1999). Women's empowerment is a key process, particularly within the rural Andes, where women suffer from discrimination more than men (Centro Bartolomé de las Casas [CBC] et al., 2014; De la Cadena, 1995; Meentzen, 2007), even inside their communities (Canessa, 2012). Discrimination and racism are then coupled with gender dimensions (Canessa, 2012), as we can observe in rural areas of the Cusco region (De la Cadena, 1995; Ypeij, 2012). Gender inequalities are manifested, among others, through limited school and educational access for women (Canessa, 2005).

In this respect, the story of Margarita, who is fluent in English, presents a challenge to this otherwise worrying situation. And her case is not exceptional in Chinchero. According to my fieldwork observations, other women weavers from different textile centers speak English very well. They were able not only to explain but also to respond in English. The case of Chinchero is even more impressive considering that in other areas of the Cusco region, the situation is characterized by monolingualism. Comuneras, mainly the older women, usually speak Quechua and a little Spanish. Mastering a foreign language such as English is more the exception than the rule. In itself, the act of speaking in public is uncommon in comuneras who are characterized by a certain shyness ("submissive shyness" to take up the words of the anthropologist Elyane Zorn, 2004, p. 166). That is something that contrasts the jokes emitted by female weavers of the Chinchero textile centers.

Given the "educational poverty" in the Peruvian Andes (Franco, 2007) that falls mainly on women, this paper shows possible improvements in education

\footnotetext{
${ }^{5}$ For a further discussion of the concept, see for instance, Rowlands, 1995; Cornwall, 2016; Wong, 2003.
} 
aspects. I argue that these improvements -accompanied by the income generated by the textile activity-facilitate comuneras'empowerment. I will develop this argument based on the case of Chinchero, which, as previously indicated, is favored by a series of geographical factors and tourism promotion. That makes it possible to relativize the tourism effects on women's education and empowerment, at least comparing to other areas of the Cusco Andes. Outside the Andean region, some studies emphasize the positive effects of tourism on women's empowerment (Tinker, 2006) on an economic, psychological, social and political level (Movono and Dahles, 2017), even though there are still some issues to resolve like the double workload (Duffy et al., 2015). Tourism can offer business opportunities and independence for women (Arroyo et al., 2019; Çiçek et al., 2017), which are key factors to promote women's empowerment. In this respect, Maria Kousis (1989) demonstrates the importance of economic factors brought by the mass tourism market in Crete to renegotiate the men-women relationship in households. Other works, instead, challenge these effects demonstrating limited impacts (Aghazamani et al., 2020; Alrwajfah et al., 2020; see also the case of rural tourism in Cusco in Knight and Cottrell, 2016) due to gender inequalities and segregation of women (Hutchings et al., 2020), which are, somehow, linked with a gendered division of labor (Pritchard and Morgan, 2000; Zelizer, 2000). It is noteworthy to remind that the concept of empowerment is a multidimensional concept and not only related to tourism. This paper focuses on the relationship between tourism, education, and women's empowerment that have been under-researched in the literature, despite the importance of education in terms of women's empowerment, for instance, in Andean rural areas (Canessa, 2005; Meentzen, 2007; Ypeij, 2012) and Mexico (Babb, 2012). Although some works demonstrate that tourism can foster women's education, for instance in the Peruvian Andes (Arroyo et al., 2019) and Turkey (Çiçek et al., 2017), they refer to institutional education. Here, attention will be also paid to tourism as an education platform on its own through women-visitors interactions.

To demonstrate this relationship, I will structure this paper into five parts. The first section presents the methodology used in this study, including the research context. The three following sections deliver the results of my ethnographic research. In the second section, through the textile activity, I will argue the idea of tourism as a monetary and restructuring resource, with positive and negative impacts for female weavers. In the third section, I will focus on tourism's effects on education, also seen as a resource derived from tourism, in particular through textile demonstrations. Then, I will end with the tourism's effects on women's empowerment, articulating the two sections previously developed. I thus argue that there is a relationship between monetary and educational elements and women's empowerment in the Cusco Andes, also taking into account certain factors that limit a more generalized empowerment. The last section elaborates some final reflections and interrogations that invite to carry out future studies on the subject. From an ethnographic research, this paper seeks to contribute to tourism studies and their intersectionality with gender and education studies. Its main contribution to the Social Sciences is to analyze this triple relationship from a broader approach to education, in which tourism not only allows investment in institutio- 
nal education but also becomes an educational platform to acquire, practice and improve linguistic (English and Spanish) and public speaking skills of the person who interacts with tourists.

\section{METHODOLOGY AND RESEARCH CONTEXT}

The data used here is based on an ethnographic study that I carried out in Chinchero in October and November of 2014 and some months of 2015 and 2017. ${ }^{6}$ During this period, I was able to conduct interviews and on-site observations in a dozen textile centers ${ }^{7}$ assuming the role of tourist, buyer and anthropologist. Almost all of the interviews and observations were carried out within these centers. The only exception was when I accompanied a French tourist group as a translator from Spanish to French during a textile demonstration in a local house (see above Photo 1).

Participant and direct observations were carried out at these centers, talking with weavers and observing interactions between colleagues and activities before, during and after visits. I tried to take some weaving lessons at the beginning of the research, both as a strategy to get contact with weavers and to experience participant observation concerning weaving activity. Even though I did not pursue these lessons, it helped me to appreciate the many intricate facets of weaving that often take years to master and are passed on through the generations. I also did participant observation playing the buyer's role through which I could obtain information given when someone buys an item from a textile center. This moment was also an opportunity to hear and interact with other tourists and listen to seller-buyer dialogues. Besides, I conducted 18 semi-directive interviews with weavers, mostly women ( 16 women and 2 men) working in the Chinchero textile centers and, to a lesser extent, working at home (Rosa and her mother). As evidenced by the story told above, the textile demonstrations are done by women. While men can be seen in rare cases, I have never witnessed a situation in which men are involved in textile demonstrations. The dominant female practice of the textile activity is key to understanding the tourism's effects on gender relations and women's empowerment that I will develop in this paper.

Interviews were performed before and after the textile demonstrations, without any tourist presence. The time of interviews varied then depending on tourist visits. While some lasted few minutes (stopped because of the arrival of visitors), others lasted longer, between 30 to 75 minutes. Sometimes, I resumed the interviews

${ }^{6}$ The ethnographic material I use here was produced within my PhD research, which did not focus solely on Chinchero but encompasses other rural and urban areas of the Cusco region.

7 The exact number of textile centers is uncertain. Ypeij (2013, p. 72) mentions a dozen textile centers, which is in line with what I observed in my study in 2014. Nonetheless, other works count about forty textile centers, apparently taking into account centers in the surrounding area, not only the rural town of Chinchero (see Gonzales Salazar, 2017, p. 72). 


\begin{tabular}{lcc}
\hline \multicolumn{3}{c}{ FIGURE 1. ILLITERACY RATE IN THE CUSCO REGION (2007) } \\
\hline \multicolumn{1}{c}{ District } & Women (\%) & Total (\%) \\
\hline Pisac & 28.1 & 19 \\
\hline Chinchero & 23.3 & 14.5 \\
\hline Qolqepata & 52.2 & 35.5 \\
\hline Cusco region & 21 & 13.9 \\
\hline
\end{tabular}

Elaborated by the author. Source: http://censos.inei.gob.pe/Censos2007/Pobreza/ (consulted on 5 October 2021).

with the same person days after, above all if the interview was too short or there were significant elements for the research during the first encounter. Interviewed people were between 21 and 62 years old, all Quechua native speakers but speaking Spanish very well. I also included an interview with the treasurer (ecónomo) of the Church of Chinchero because of its relevance regarding intergenerational changes and women's empowerment in Chinchero.

The ability of locals to speak Spanish easily with foreigners shows the particularity of the research context in Chinchero. There, women dominated this language without any problem, unlike other rural areas of the Cusco region where women (except young women) were unable to speak Spanish and remained shy when talking with foreigners. The contrast is impressive compared to regions like Q'eros communities (sometimes called Q'eros Nation, Nación Q'eros) that are less linked with the Cusco tourism market. While carrying out my research, many women did not speak any Spanish and I could not access to their discourse (if any translation from male villagers). In the village of Chawaytire (Pisac district) where Andean textiles were also produced and sold to tourists, women were less talkative with visitors. At best, they used Spanish or English to refer to the price, but they could not have a conversation, since they usually needed translation in Quechua from guides (if any) or male villagers. This situation is at least partially linked with the significant illiteracy rate in rural areas with an overrepresentation of women's illiteracy (Figure 1). Though the illiteracy rate remains considerable in Chichero, the rate is lower than in other rural places in the Cusco region.

Chinchero also has another particularity. As mentioned before, it is part of the Sacred Valley tourist circuit which makes it a touristy town much more so than other rural areas in the Cusco region. Thus, Chinchero is very well inserted into the classical mainstream tourism in the region, with numerous tourists arriving from morning to evening all year. That is less the case for other places like Chawaytire, although the on-site textile offer is closed linked to the tourism market.

Besides, socioeconomic disparities exist from one province or district to another within the Cusco region. For example, the district of Pisac, Chinchero and Qolqepata (where is located a part of the Q'eros communities) have a monetary poverty incidence of $65.6 \%, 71.9 \%, 92.6 \%$, respectively. These values are above the 


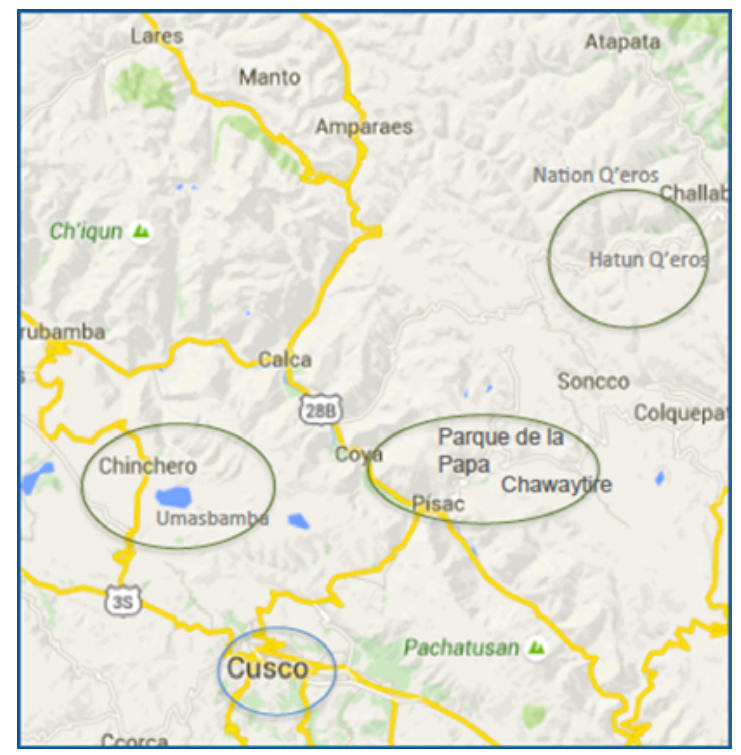

Figure 2: The Cusco region. The map shows the city of Cusco and other rural places mentioned in the article. Note that each Peruvian region, like Cusco, is divided into provinces and districts. Source: Google Maps. Modified by the author.

Cusco region's incidence (57.4\%; the national incidence is $39.3 \%) .{ }^{8}$ It is noteworthy that women weavers in Chinchero do not have the same socio-economic status. As we will see in this paper, some are better off than others, particularly those who have the economic capital to become entrepreneurs while others remain workers. However, it would be hard to draw up socioeconomic profiles for each interviewed person, since the research was performed in textile centers, paying less attention to their living conditions. The latter could have been possible to observe if I would have conducted research within households to better understand and compare weavers' particular socio-economic situation. As I will highlight in the conclusion, it would have been helpful to contrast discourse on women's empowerment with actual changes within households.

${ }^{8}$ Data obtained from the Peruvian Statistics Institute (INEI): http://censos.inei.gob.pe/ Censos2007/Pobreza/ (consulted on 5 October 2021). 


\section{TOURISM: ECONOMIC RESOURCE AND STRUCTURING RESOURCE}

TOURISM "CALLS TO THE MONEY"

Works such as that of Annelou Ypeij (2012) particularly emphasize the economic importance of textile activity for the weavers of Chinchero, with selling merchandise to tourists being their "ultimate goal" (Ypeij, 2012, p. 28).

It is precisely this ultimate objective that seemed evident to me in my fieldwork since people tried by various means to "sell at least a little bit," as several women weavers verbalize. For example, on one occasion, a weaver thanked me for buying a pencil case, being "the first sale" (primera venta) and that allows her to "call luck" (llamar a la suerte) (Delmy, 05/20/17). This expression is in line with Jane Henrici's (2002) idea of "calling to the money" presented in her research in the rural town of Pisac (Cusco). In neighboring communities of Pisac, women dress in their trajes tipicos for tourist purposes, either to sell their products or to be photographed in exchange for money.

Following this idea of calling to the money or luck, and as observed in Chinchero, the textile activity effectively constitutes a source of income, at least a supplementary one, which increases as the number of tourists grows. As mentioned in the introduction, elements such as Margarita's jokes facilitate sales in a town that has already benefited from tourist frequentation within the Sacred Valley circuit.

The economic interest in textile activity explains the rise of the textile demonstrations format since the 1990s, not only in Chinchero ${ }^{9}$ but also in the rest of the Cusco region (see Pérez Galán, 2012, p. 185). This rise occurs despite the growing competition and commissions that weavers must pay to tour guides oscillating, according to my interlocutors, between 10 to $30 \%$ of sales (20\% according to Ypeij, 2012, p. 29). ${ }^{10}$ In a recent study, Luis Gonzales Salazar (2017) shows the profitability of working in textile centers, not only compared to agricultural activity but also other businesses in the rural town of Chinchero, motivating many women to work in these centers. In addition, there are other sources of income around textile centers, mainly food services and beverage sales to tourists.

The weavers' discourse, during my fieldwork, highlights the economic importance of tourism-related textile activity, taking into account the depreciation of agriculture and the precariousness of other jobs carried out by comuneros and comuneras. Without downplaying this importance, it is noteworthy that this can be overvalued to an external agent such as myself to give a good impression to the buyer, mainly by women who manage the textile centers. It is the case of Naty who,

9 According to Adolfo, a weaver from Chinchero, the origins of the textile centers date from the creation of the Centro de Textiles Tradicionales del Cusco (CTTC) by Nilda Callañaupa (on the CTTC history, see Ypeij, 2012, pp. 28-29; Gonzales Salazar, 2017, pp. 69-72).

${ }^{10}$ See also on this topic in Peru: Asensio, 2016; Ypeij and Zorn, 2007; Zorn, 2004. 
during our interview, emphasized the importance of the income generated in favor of female weavers, comparing it with that of other centers that benefitted only the "bosses" (patronas) or their families.

Although the economic contribution of the textile centers is undeniable, Naty's speech reveals asymmetries and power relations between the weavers, as I observed around women like Naty who received me and spoke on behalf of the rest. There are thus hierarchies within textile centers between employers and salaried workers or employees. The former set up the rules of the game (e.g., sales commissions to each weaver) and tend to monopolize more sales stands in the textile centers, causing their income more likely to be higher. Gonzales Salazar (2017) cites the case of an employer who controlled half the sale stands. The author speaks in terms of "coordinators" or "owners" who rent sale stands. Within these hierarchical relationships, this author evokes insults and mistreatment that some weavers must endure. In 2017, Adolfo, one of the few male weavers in Chinchero, confirmed such hierarchies. He even mentioned strikes by some weavers to try to improve their situation. Sometimes the owners are the only ones who speak English, which influences sales capacity compared to the rest. However, several women decide to endure the "abuses" (term used by some weavers) hoping for better job prospects or to create their textile center in the future.

Consequently, although work in textile centers "calls to the money," its distribution is asymmetric. This asymmetry characterizes textile activity globally, if we refer, for example, to the power relations between guides and weavers in textile centers (Terry, 2019: chap. 6; Ypeij, 2012). The same is shown by Gonzales Salazar (2017) among weavers and merchants in the central square of Chinchero. This situation makes it possible to challenge global economic benefits mentioned previously.

In addition to these power relations between women, there could be power relationships between women and men inside the textile centers. It is true that, in most cases, women take the reins of these centers (see Chávez Human, 2012; Gonzales Salazar, 2017; Lyon, 2013; Ypeij, 2012, 2013). However, gender power relations cannot be excluded since some men assume the role of administrators. Gonzales Salazar (2017, p. 74) cites, for example, the case of a weavers' association in which men are in charge of accounting and contacts with tour operators. While Asensio (2016, p. 350) mentions the feminine feature of the textile activity in the Cusco region, he shows cases where men assume the head of the group (see the case of the Ocongate association in Asensio, 2016, pp. 351-353).

The elements mentioned previously allow us to sustain the idea that tourism is both an economic resource and a "structuring resource" (recurso estructurador) (Gascón, 2005). The latter is understood to be the one that is presented as the most important in the socio-economic structuring of the community, meaning those who control or possess it in greater quantity are the ones with greater economic capacity, excluding those that have it in less quantity (Gascón, 2005, p. 293). In his work on Amantani (Peru), Jordi Gascón pertinently shows how tourism in the contemporary Andes has become the structuring resource that establishes the "peasant differentiation" (Ibid.), here between comuneros, particularly among women weavers. Some are those that control the tourism resource more than others. We will see, 
later on, that education also becomes a resource derived from tourist activity which is in direct relation to textile marketing.

"CALL TO THE MONEY", BUT AT WHAT PRICE? EMANCIPATION OR WORK OVERLOAD?

We should also consider weavers' work overload, including unpaid, non-salary work, mainly domestic tasks and agricultural activity. In my study, several weavers affirmed the need to combine their work in the textile centers with their responsibilities at home. For example, once at noon, Maria quickly told me when I wanted to talk to her: "I can't stay now. I have to run home and cook [for my children]." I realized that the textile centers were emptied around 1 p.m., at which time several women returned home to take on household chores. Others indeed stayed in textile centers to welcome tourists (at that time, less numerous since the vast majority arrive at the end of the day when the Sacred Valley tour ends).

This observation brings to light generational differences because, contrary to weavers like María, in her thirties, younger women, single and without children, can stay in textile centers at that time. Julia, another weaver, confirms this trend in which women tend to accumulate work inside and outside the textile centers. They take care of the children, while men take care of the agriculture, as Julia affirms. However, this home responsibility does not relieve women of agricultural work. Once Delmy, coordinator of a textile center, had to leave the textile center when I wanted to interview her. She explained to me that she had to work in the communal potato harvest for May. Although she did not complain about it, this example shows the female work accumulation criticized by other studies in Chinchero (e.g., Gonzales Salazar, 2017) and elsewhere in the Cusco region. For instance, in their research on community-based tourism, Fuller and Pérez Galán (2015) denounce the continuity of unpaid domestic work along with the reproduction of female tasks and roles in tourism (cooking, cleaning, etc.). These criticisms call into question the "pre-existing gender system" (Asensio, 2016, p. 353) still in force in the Cusco region.

Although some like María do not question the domestic role assumed by women (and therefore the work overload), some changes show improvements in Chinchero. Delmy told me, for example, that today women "have a voice" and can "negotiate housework." Looking at her son during our interview, she added: "We teach him to cook so later he can do it in the future." These words are significant to progressively build a change in the new generations. The relevant thing is that this change has been taking place for some time now, and it is closely related to the textile activity. That is what the words of Jerónimo, treasurer of the Church of Chinchero with whom I spoke on the subject, reveal. He affirms that men have progressively transformed their look towards women, accepting a change in male responsibilities at home. Before, it was "strange" for a man to make purchases at the market, a situation that today seems "normal" (Jerónimo, 04/24/17). Fredy-coordinator of a textile center together with his wife- and Adolfo -weaver in that center-affirmed that "machismo" is felt less today and that women are seen as "workers" because they bring home money (Fredy 05/20/17; Adolfo 05/22/17). That contributes to 
the "capital of honor" (capital de honor) mentioned by Angela Meentzen (2007, p. 216) that inspires much respect and better treatment of husbands towards wives (pp. 230-231). It is precisely worth highlighting the reflective capacity of men whose acts (like women) configure gender relations daily. This reflective capacity is a significant element for women's empowerment, as we will see later on. The acquired capital of honor allows challenging the criticisms mentioned previously about the continuity of gender inequalities regarding people's asymmetries and work overload.

However, it is noteworthy that these improvements seem to benefit leading weavers, the parties who play a significant role in textile centers and who are usually in a favorable hierarchical position, to a greater degree. That is the case described by Ypeij (2013) about Nilda Callañaupa from the Centro de Textiles Tradicionales del Cusco (CTTC) weavers association ${ }^{11}$ and Marlene Callañaupa (they are not from the same family). This anthropologist emphasizes that both have become successful entrepreneurs, traveling abroad and giving multiple conferences. This example recalls the asymmetries that exist between weavers of textile centers, with certain abuses of power that target, for instance, Nilda Callañaupa (Pérez Galán and Fuller, 2015, pp. 106-109; Pérez Galán, 2012, p. 184).

\section{EDUCATION AS A RESOURCE}

Despite the aforementioned disparities and tourism being a structuring resource among comuneros, education is one of the non-monetary benefits appreciated by women weavers. Their speech underscores the importance of education for their future career prospects or that of their children. The investment of education, or the change of monetary capital into educational capital, has been approached by other works, both in Chinchero and in the Andean region (Canessa, 2012b; Garcia, 2015; Meentzen, 2007; Ypeij, 2012; see also the importance of education as capital in Bourdieu and Passeron, 1964). What is new here is the remarkable linguistic and oratory skills cited in the introduction when I talked about textile demonstrations explained in English. This finding allows us to adopt a broader perspective on education that is not limited only to institutional aspects but also includes learning in general, i.e., practical knowledge that is acquired outside of schools or institutes, which is built thanks to the interaction with tourists. This stance allows us to observe the effects of tourism on education, not only for children but also for the female weavers themselves.

Within this perspective, education will be seen here as a resource derived from tourism, as other resources previously mentioned: the monetary and the

${ }_{11}$ The CTTC groups ten weavers associations in different communities of Cusco: Accha Alta, Acopia, Chawaytire, Chinchero, Cumbivilkas, Patabamba, Pitumarka, Sallac, Mawaypampa and Huacatinco. Its objective is to promote the textile "tradition" and provide a better income to comuneros (mainly weaver women). For more details, see Callañaupa (2007). 


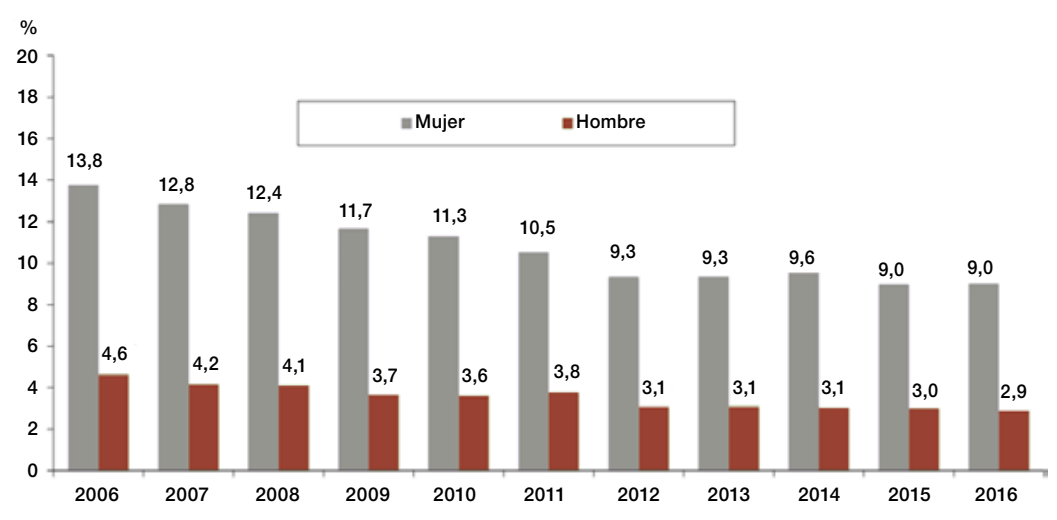

Figure 3: Illiteracy rate in Peru: women vs men (2006-2016).

Women are in grey and men in red. Source: INEI, 2017, p. 81.

structuring resource. It is, in a way, capital obtained through tourist activity, here through textile demonstrations, which generate income, but also educational capital for women weavers. That is even more relevant, taking into account educational poverty within the Andean context.

\section{EDUCATIONAL POVERTY IN THE RURAL ANDES}

Education must be understood as a valuable resource within the Andean context as it has been an unevenly redistributed resource. Susana Franco (2007) describes the critical situation in Andean rural areas, where "educational poverty" affects mainly comuneras. In the Aymara Andean region, Angela Meentzen (2007, pp. 32-34) brings to light the educational deficiencies that affect indigenous women and contribute to the "gender gaps." This situation favors illiteracy and monolingualism, especially in older women. In Peru, the illiteracy rate is roughly three times higher among women (Figure 3), and especially among those from rural areas speaking a native language as a mother tongue (Figure 4; see also above data from the Cusco region in Figure 2).

For her part, Marisol de la Cadena (2004) insists on the ideology of education as a means of development, assimilated in such a way in Cusco by mestizo or autochthonous population (see also the case of the Aymara in Bolivia in Andrew Canessa, 2012b, chap. 6). This type of ideology reinforces the interest in education as a valuable resource for comuneros. Despite the efforts of the State to remedy this situation, for example, through the Intercultural Bilingual Education (EBI, Educación Bilingüe Intercultural), educational poverty in the rural Andes is still current, and the EBI is not a viable solution (see criticisms in Gajardo et al., 2008; Garcia, 2015, pp. 124-125; Thénard, 2006; Steckbauer, 2000). 


\begin{tabular}{lccc}
\hline \multicolumn{3}{c}{ FIGURE 4: ILLITERACY RATE IN RURAL AREAS IN PERU (2016) } \\
\hline & CATEGory & Native SPEAKER & SPANish SPEAKER \\
\hline Women & $33 \%$ & $8,5 \%$ \\
\hline Men & $16 \%$ & $5,3 \%$ \\
\hline
\end{tabular}

Elaborated by the author. Source: INEI, 2017, p. 83.

The poverty issue is effectively manifested in a multidimensional way (Bey, 2003; Herrera, 2002; Fusco, 2007; Stewart et al., 2007; Terry, 2011: 8-9), with education being one of the problematic elements that afflict comuneros, mainly women. In my $\mathrm{PhD}$ research, I was able to verify critical situations in remote areas, such as Q'eros, neglected by the national educational system. Having seen a 6-year-old boy with a frontal flashlight trying to do his math homework in the dark and sitting on the floor made me realize all the difficulties that impede children's educational development at the same level as a boy or a girl from the city who enjoys certain comforts.

This overview allows us to contextualize the case of Chinchero, which is located in a rural area and suffers from this educational poverty that affects people's future professional and employment prospects and has repercussions on their quality of life. Although the case of Chinchero is likely less critical than other rural areas such as Q'eros, the need for a "better education" (mejor educación), as Chinchero people underline, cannot be ignored.

\section{INVESTING IN EDUCATION}

To deal with the educational poverty issue, the rural population seeks different means to improve their education, at least that of their children. Several interviewed weavers emphasize the importance of money obtained working in textile centers (via sales) for their children's education. By education, they refer not only to college but also professional institutes and universities. They thus project investment in education in the medium and long run.

As far as primary education is concerned, the idea of "free education" in public schools (to which every boy and girl has the right) is questioned. The reality is that education costs, as Canessa (2012b, p. 201) shows in Bolivia, which is is also true for Peru, where parents must buy school supplies and uniforms. In addition, children's education implies an investment since it represents a loss of additional labor in agriculture (Ibid.). Since education requires monetary investment, work in textile centers becomes an attractive economic alternative for weavers, as shown by other studies in Chinchero (Gonzales Salazar, 2017, p. 88; Ypeij, 2012, p. 29). That is better understood if taking into account the profitability of tourist market-related textile activity, with the example of Chinchero being even more profitable to work in textile centers. Thanks to this activity, weavers like Carmen have been able to 
provide higher education to their children. This weaver speaks, for example, of her daughter who studied at a tourism institute and, later, opened her tourism agency in Cusco city.

But it's not all about children's education. As I could observe, some women weavers also invest in their education. For instance, Thania financed her studies at a tourism institute to become a guide, thanks to her work in a textile center (Thania, 10/22/14). In the same way, Adolfo affirms that other young weavers, like himself, financed their English studies in Cusco city (Adolfo, 05/20/17). In 2014 Sara was studying tourism at the Cusco University (UNSAAC, Universidad San Antonio Abad del Cusco). Far from being an exceptional case, university friends from UNSAAC, with whom I was able to talk, told me that they knew several university students from Chinchero who were studying tourism or anthropology. This situation is in line with what was observed by Pérez Galán and Fuller (2015, p. 114), pointing out a new generation of young people with university education related to tourism. Sara is an example of those who combine study and work in textile centers. In fact, for her, textile demonstrations to tourists allowed her to exercise her English, which, at the same time, is also advantageous for her career.

TOURISM AS A PLATFORM FOR LEARNING FOREIGN LANGUAGES AND PUBLIC SPEAKING

The case of Sara serves as an example to understand how tourism, through the explanations provided during textile demonstrations, serves as a learning space in itself. This understanding makes it possible to broaden the spectrum of tourism's effects on education in a dialectical way: on the one hand, tourism income finances education; on the other, interaction with tourists promotes education and enables to put it into practice on the spot.

Margarita's story in the introduction testifies to the skills that female weavers acquire in practice. Language institutes or universities are often questioned for providing only theoretical knowledge. On the contrary, textile demonstrations allow Quechua-speakers women to practice not only Spanish but also English. As Adolfo points out, people from Chinchero have practical knowledge and develop spoken English much better than their classmates from Cusco (who are more fluent in written English).

I attended other textile demonstrations in which women weavers had an advanced English level. For instance, Margarita's case shows a remarkable ability to joke in English, which is not easy to perform in a foreign language. Beyond what I observed in situ, several YouTube videos posted by tourists or by members of the textile centers themselves corroborate the fact. In these videos, we can notice, for example, some young women who simultaneously dominate three languages: Spanish and English translation with tourists, and Quechua among weavers. Although these linguistic skills and the capacity to switch languages varies from one weaver to another, textile demonstrations progressively allow women to develop their skills by practicing with tourists. 
In this regard, Jerónimo uses an intergenerational comparison pointing out the most favorable current situation, especially for young Chinchero women. Speaking of his mother, whom he describes as an "illiterate weaver," he affirms that the new generations not only finish compulsory school but nowadays they also go to institutes and universities. Jerónimo also mentions that many young women study English in language institutes. Moreover, their curiosity allows them to learn key words in some languages with tourists: "How do you say this in...?" Jerónimo thus underlined the participation of tourists in the language learning process. Indeed, sometimes, that is manifested through some words learned in English, mainly numbers or objects' names, helpful for selling their products. On some occasions, I could even hear terms in French, for example, "trente soles" (thirty Peruvian soles) indicating a sweater price. Although this kind of learning is much more occasional and less required during textile demonstrations, it shows how tourism facilitates the acquisition/reinforcement of a foreign language. Comuneras learn by imitation and repetition, by elbowing and listening to tourists. The need to explain the handmade textile process and sell products motivates today to learn foreign languages, mainly English, due to its importance in the tourism market.

Beyond participating in language learning, textile demonstrations facilitate building oratory skills while performing textile process explanations to tourists. If we refer to the introduction story, Margarita explains the stages of the handmade textile process while joking with tourists. Anyone who has spoken in public knows and experiences the possible difficulties in such an exercise. It is not something learned overnight. It needs continual practice and performance. The jokes are a significant element of the acquired skills, something observed in several textile centers. Like Margarita kidding about the "bone of the tourist who didn't want to buy anything," other weavers joke about the "Inca shampoo" or saktana-root used to wash sheep or alpaca wool- that would "cure" baldness, a joke also used by Margarita addressing a tourist. Others talk about the "Andean kiss" to explain the use of the cochineal employed to dye threads of red or derived colors (around twenty shades according to different weavers). Painting their lips red with the cochineal dye, these women amuse the public by stating that the "Andean kiss" is infallible, conquering anyone with their kisses. Textile demonstrations usually contain these kinds of jokes with which women explain the handcrafted textile process, adopting a pleasant and participatory pedagogy with the public. It seems to me that this way of explaining the textile process creates empathy between tourists and women weavers, which is then "rewarded" with sales (since textile demonstrations are free).

In the Cusco region, Chinchero is a surprising case study, considering the shyness that often characterizes women in the rural Andes. I am referring, for example, to communities of Pisac and Q'eros, with which I have worked for academic and professional reasons, where I realized the difficulty in speaking with comuneras, especially when you are a man and Spanish-speaking. They hardly take the floor in public, but if so, they do to a lesser degree than their male counterparts, especially when women have to speak in Spanish. Zorn (2004, p. 166) qualifies this comuneras' situation as "submissive shyness" (see also Meentzen, 2007, p. 301). 
Comparing the case of Chinchero with these communities reveals changes generated in some women in rural areas thanks to the tourism market. Q'eros communities (excluding male shamans associated with mystical tourism) are less linked with the Cusco tourism market. In contrast, Pisac communities are closely related to the Sacred Valley tourist circuit that frequently culminates with the visit of Chinchero. Having worked as a coordinator for the Potato Park's agro-ecotourism program (2012), I know the tourism dynamics in the Pisac area well to be able to say that its frequency is lower than that of Chinchero. Although the Park's agro-ecotourism program includes services of female weavers of the Nawpa Away association, they do not have the linguistic and oratory skills shown in Chinchero. That is possibly due to the lower tourist frequency that would allow these other communities to develop and practice these skills. Nawpa Away's weavers are mostly Quechua-speakers. They require comuneros or guides to translate comuneras' textile explanations. Having observed (to a lesser degree) other experiences in the Pisac region, the situation is not comparable with Chinchero comuneras who work in textile centers.

This comparative passage makes it possible to underline tourism's effects on education, which vary according to the tourist importance of the place. Being inserted into the Sacred Valley circuit, Chinchero receives tourists every day, and many of them visit the textile centers. The example of Chinchero allows challenging studies in other Latin American contexts, such as Florence Babb's (2012) study on Mexican indigenous women. This author states that these women suffer from difficulties in accessing education and developing language skills that would be essential for them to interact with tourists. Contrary to Babb's argument, the Chinchero example shows how interaction with tourists favors comuneras' educational development.

\section{WOMEN'S EMPOWERMENT: PERSPECTIVES, LIMITS, QUESTIONS AND CHALLENGES}

What has been previously developed allows us to address the women's empowerment issue in the rural Andes. I will briefly return to the economic and, especially, educational aspects formerly treated to question this empowerment, with its possibilities and limits.

To better understand the significance of the changes related to the tourism market in Chinchero, we must adopt a comparative perspective, both diachronic and synchronous. From the historical point of view, numerous works show how, since the Spanish colonization, indigenous people have suffered asymmetrical relationships with non-indigenous populations. These have been marked by power relations and racial and ethnic discrimination in Peru (Carrillo, 2005; Fajardo, 2002; Labrousse, 1985; Steckbauer, 2000) and more widely in Latin America (Bastian, 1991; Chonchol, 1995). In the Peruvian case, independence did not mean a radical change since "the marginalization of indigenous people continues" (Contreras and Cueto, 2013, p. 74; my translation). The hacienda system (see Pumallica, 2016) and 
the violence of the Sendero Luminoso terrorist organization are just a few historical examples of the regrettable situation that indigenous people have experienced. These situations mainly affect indigenous women, as Susan Kellogg (2005) argues in the Latin American context. This ethnohistorian highlights the critical situation in the Andes characterized by female submission, as shown by other works in Bolivia (Canessa, 2012b), Ecuador (Crain, 1990; Voirol, 2016), and Peru (de la Cadena 1995, 2004; Poole, 1997; Thorp and Paredes, 2010).

This discrimination, which falls heavily on women in the rural Andes, is still in force. Meentzen (2007) shows, for example, the existing racial and gender discrimination in Puno (Peruvian Andes), where Aymara women suffer from domestic, physical and psychological violence. A study conducted by Bartolomé de las Casas Center also highlights this type of discrimination against girls in the Cusco region (CBC et al., 2014). This discrimination materializes, for example, in acts such as the forced sterilization of comuneras by the Fujimori government (Barthélémy, 2004).

These antecedents in the Andean region, both past and present, allow questioning the issue of women's empowerment through the case of Chinchero. Previously, I compared the Chinchero weavers with others from Pisac and Q'eros, where educational poverty and shyness are still part of the reality in the rural Andes, especially for women. That is why the example of Chinchero is significant: it shows the possibilities that tourism offers, not only as an economic resource but also an educational one, despite an unequal distribution (especially in monetary terms), with tourism being a structuring resource (Gascón, 2005). According to Canessa (2005, p. 147), in the Andean rural area, female autonomy is more likely when there is a "source of cash" and when the ability to speak at least Spanish is guaranteed, mainly promoted with "expanded school" access. Both elements are present in the case of women weavers of the textile centers in Chinchero. In this case, it is no longer about primary or secondary education but higher education as well. To these, we have to add the practical education carried out thanks to daily interactions with tourists. This practical education reinforces language proficiency not only in Spanish but also in foreign languages, mainly English.

The combination of economic and educational aspects promoted by the tourism market in Chinchero ${ }^{12}$ allows us to better understand the exceptional case of Chinchero concerning women's empowerment, being much more visible than other rural areas in the Cusco region. The discourse of Jerónimo, Fredy and Adolfo allows us to perceive a change of perspective towards women in terms of gendered domestic roles distribution, thanks to women's economic contribution to the household. This kind of male discourse shows that changes also come from men, which result in "less macho relationships" (menos machistas), as stated by some women weavers. At the same time, the example of the child whose parents taught to cook, reveals

12 There is a third element related to the appreciation of ethnic identity (see Terry, 2019, chap. 6) that I do not address here. The textile demonstrations represent a way for the weavers to highlight their identity, appreciated by tourists (see also Ypeij, 2012). 
significant bases for a continuous change in the gendered relationship in the future. This evolving situation challenges Kousis's (1989) conclusion in the case of Crete. While she demonstrates that the mass-tourism market helps to renegotiate male-female relationships in households, she stresses the economic factors more than the ideological ones. The case of Chichero shows that economic, educational and ideological factors are all necessary to build women's empowerment.

However, it would be an exaggeration to argue for the existence of a generalized women's empowerment in Chinchero (if we refer to the scope of my study that focuses only on women weavers of the textile centers). The employer-employee hierarchical configuration reveals more accessible empowerment for some women than for others. This unequal empowerment depends on the resources they possess, mainly their capacity to manage the textile centers. These asymmetries between women show how class inequalities overlap with gender inequalities (de la Cadena, 2004; Femenías, 2005; Gill, 1993; Weismantel, 2005; Zorn, 2004). Hierarchies between female weavers in the textile centers show that empowerment realization is not merely linked to asymmetrical relationships between men and women but also between women.

The case of the CTTC, cited in other studies, also allows us to discuss broader asymmetries and power relations in the Cusco region since this textile organization regroups different associations of weavers from several communities of the Cusco region. Some authors (Pérez Galán 2012: 184; Pérez Galán and Fuller 2015: 106-109) strongly criticize Nilda Callañaupa, the director and founder of the CTTC, for recreating these inequalities and abuses, despite economic contributions and revitalization of the textile activity thanks to the CTTC as highlighted by other authors (Ypeij, 2013, 2012; Lyon, 2013; Meisch, 2009: 144-146; Zorn, 2004, 106-107). I also heard reproaches from former CTTC weavers in Chinchero and Chawaytire (Pisac). These criticisms challenge the optimism with which Ypeij (2012, 2013) describes the case of Nilda Callanaupa and another leader from Chinchero. Thus, women's empowerment resides in a few, or at least is embedded in hierarchi$\mathrm{cal}$ and power dynamics between comuneras. It is not only a question of whether or not there is women's empowerment, but also of acknowledging who benefits from it, often at the expense of others.

We are thus facing ambiguous effects on women's empowerment through tourism. As Pérez Galán and Fuller (2015, p. 99) emphasize in their study in Cusco and Puno, these effects are "heterogeneous," ranging from gender empowerment to exploitation, job insecurity or work overload. Therefore, there is no generalized women's empowerment, nonetheless, tourism-related textile activity can favor men-women domestic tasks distribution or generate economic independence and "security from their partners" (Pérez Galán and Fuller, 2015, pp. 105, 112-113; my translation). 
This paper shows us how tourism, beyond its economic contributions, favors women's education and empowerment in the rural Andes. However, the latter is not generalized to the entire Cusco region, and there are still considerable inequalities in Chinchero, inside and outside the textile centers. While the economic and educational aspects are central to understand tourism's effects on women's empowerment, tourism cannot ensure this empowerment alone. Political and legal aspects are also fundamental in consolidating women's empowerment, as highlighted by Meentzen (2007, p. 322). Like this anthropologist, Pérez Galán and Fuller (2015) criticize, for instance, the lack of political participation of comuneras who do not have voting rights in community assemblies (asambleas comunales) as is the case in the communities of Q'eros and Pisac. If the status quo appears to remain in these communities, things seem to be changing in Chinchero. In the last interview with Adolfo in 2017, he told me that comuneras today have a voice in the voting process and that even widows or single women can present themselves as regidores (a local political entity). This aspect remains to be explored. If confirmed, Chinchero would be taking a further step in women's empowerment issues linked to political elements that reinforce it.

In the same way, there are other questions that I have not been able to address in-depth or that require further study to provide analysis over time. For example, Canessa (2012a, p. 113) wonders about changes in gender relations within households: the possibility that women earning more money thanks to tourism generates violence because of certain jealousy from their husbands or if they are taking advantage of their wives' earnings. My research cannot answer such a question, having not studied the dynamics in households. However, the discourse of Jerónimo, Fredy and Adolfo allows us to extrapolate some changes in mentality and attitude in terms of domestic work distribution, although cases like the one of María show some continuity of the sexual division of work. Thus, it would be necessary to corroborate, within households, if the discourse is put in practice. In this respect, the pioneering work of Kousis (1989) in Crete demonstrates changes in rural households thanks to women's job opportunities within the tourism market. However, unlike Kousis's conclusions, there also seems to be ideological changes and not only economic ones.

On the other hand, two more questions remain: Can women's education (education in the broad sense adopted here) induce a much larger empowerment of women for future generations that can counteract, for example, hierarchies between comuneras? Will women's empowerment still be sustained by the textile activity, acknowledging that investment in education tends to train future professionals (e.g., tour guides or tourism agency owners) who will not necessarily stay in their community?

The case of Carmen's daughter, who owned a tourism agency in Cusco city in 2017, or Thania, who was studying to be a tour guide, are concrete examples that show possible reconfigurations of the current situation. When I conducted my ethnographic research with weavers in the Chawaytire community, I used the "textile renaissance" image to refer to the increasing number of Chawaytire weavers and the 
masculinization of the textile activity that accompanied this increase (Terry, 2009, 2016). Years later, I found that many Chawaytire weavers wanted their children to be professionals, leaving aside agricultural and textile work (Terry, 2019, pp. 411412; see also Terry, 2020b). Today, the Andean textile activity might be a springboard to access better job prospects. This possible trend likely follows the "ideology of education" promoted in Cusco (de la Cadena, 2004) and the urban professional model. If this hypothesis is confirmed, it remains to be studied how this socio-professional conversion affects women's empowerment that I laid out in this paper.

Although located in a specific region of the Peruvian Andes, namely Chinchero, this ethnographic research seeks to enrich the more general debate on women's empowerment. It sheds light on the importance of economic and educational aspects promoted by the tourism market, which participates in women's empowerment as a complex and multidimensional process that helps women "develop their capabilities, have a sense of control over their wellbeing and lead dignified lives" (Scheyvens and Russell, 2012, p. 422). Both individual and collective aspects are relevant, since individual empowerment alone does not necessarily lead to a broader collective and inclusive women's empowerment, as shown in the case of Chinchero. Sometimes, indeed, "empowerment for some" can be simultaneously accompanied by "disempowerment of others," as stated in Knight and Cottrell's (2016, p. 40) previous work on rural tourism in the Cusco region. If tourism can promote women's empowerment, it is not a panacea. Different factors such as particular expression of power as well as personal, socio-economic and environmental factors can influence (dis) empowerment processes (Knight and Cottrell, 2016, p. 44). 


\section{BIBLIOGRAFÍA}

Abou-Shouk, M.A., MannaA, M.T. and Elbaz, A.M. (2021). Women's Empowerment and Tourism Development: A Cross-Country Study. Tourism Management Perspectives, 37. https://doi. org/10.1016/j.tmp.2020.100782.

Aghazamani, Y., Kerstetter, D. and Allison, P. (2020). Women's Perceptions of Empowerment in Ramsar, a Tourism Destination in Northern Iran. Women's Studies International Forum, 79. https://doi.org/10.1016/j.wsif.2020.102340.

Alrwajfah, M.M., Almeida-García, F. and Cortés-Macías, R. (2020). Females' Perspectives on Tourism's Impact and their Employment in the Sector: The Case of Petra, Jordan. Tourism Management, 78. https://doi.org/10.1016/j.tourman.2019.104069.

Ariel de Vidas, A. (1996). Mémoire textile et industrie du souvenir dans les Andes. Identités à l'épreuve du tourisme au Pérou en Bolivie et en Equateur. L'Harmattan.

Asensio, R.H. (2016). Los nuevos incas: La economía politica del desarrollo rural andino en Quispicanchi (2000-2010). IEP.

Bавв, F. (2012). Theorizing Gender, Race, and Cultural Tourism in Latin America: A View from Peru and Mexico. Latin American Perspectives, 39(6), 36-50. https://doi.org/10.1177/ $0094582 X 12454560$.

BarthéLÉmy, F. (2004, May). Stérilisations forcées des Indiennes du Pérou. Le Monde Diplomatique. https://www.monde-diplomatique.fr/2004/05/BARTHELEMY/11190.

Bastian, J.-P. (1991). Amérique latine: 1492-1992, conquête, résistance et émancipation. Labor et Fides.

Baud, M., YPeij, A. and Zoomers, A. (2006). Introducción: El turismo como una estrategia para el desarrollo sostenible. In: A. Ypeij and A. Zoomers (eds.), La ruta andina: Turismo y desarrollo sostenible en Perú y Bolivia. Abya-Yala.

Bey, M. (2003). Pérou: Quelles politiques de lutte contre la pauvreté ? Autrepart, 27, 5-23. https:// doi.org/10.3917/autr.027.0005.

Bourdieu, P. and Passeron, J.-C. (1964). Les héritiers: Les étudiants et la culture. Les Editions de Minuit.

Callañaupa, N. (2007). Weaving in the Peruvian Highlands: Dreaming Patterns, Weaving Memories. CTTC.

Calvès, A.-E. (2009). «Empowerment»: Généalogie d'un concept clé du discours contemporain sur le développement. Revue Tiers Monde, 200(4), 735-749. https://doi.org/10.3917/rtm.200.0735.

Canessa, A. (2005). The Indian Within, the Indian Without: Citizenship, Race, and Sex in a Bolivian Hamlet. In A. Canessa (ed.), Natives Making Nation: Gender, Indigeneity, and the State in the Andes. University of Arizona Press.

Canessa, A. (2012a). Gender, Indigeneity, and the Performance of Authenticity in Latin American Tourism. Latin American Perspectives, 39(6), 109-115. https://doi.org/10.1177/0094582X12456681.

Canessa, A. (2012b). Intimate Indigeneities: Race, Sex, and History in the Small Spaces of Andean Life. Duke University Press Books.

Carrillo, H. (2005). La dimension étnica de la desigualdad en el Perú. In A. Adriazén (ed.), La desigualdad en el Perú: Situación y perspectivas. Desco. 
Centro Bartolomé de las Casas [CBC], Asociación Kallpa and Save the Children (eds.). (2014). Verdades no resueltas, protección infantil y derechos humanos: Resultados del concurso de investigación y estudio de casos sobre derechos humanos, ciudadanias subalternas y protección infantil en las regiones de Cusco y Apurimac-2013 (resumen amigable). Centro Bartolomé de las Casas.

Chávez Huamán, E. (2012). Chinchero for sale. Master thesis, Lima, Pontificia Universidad Católica del Perú. http://tesis.pucp.edu.pe/repositorio/handle/123456789/5703.

Chonchol, J. (1995). Systèmes agraires en Amérique latine: Des agriculteurs préhispaniques à la modernisation conservatrice. Institut des Hautes Etudes de l'Amérique Latine.

ÇıçeK, D., Zencir, E. and KozaK, N. (2017). Women in Turkish Tourism. Journal of Hospitality and Tourism Management, 31, 228-234. https://doi.org/10.1016/j.jhtm.2017.03.006.

Contreras, C. and Cueto, M. (2013). Historia del Perú contemporáneo: Desde las luchas por la independencia hasta el presente. Instituto de Estudios Peruanos.

CoRnwall, A. (2016). Women's Empowerment: What Works? Journal of International Development, 28(3), 342-359. https://doi.org/10.1002/jid.3210.

Crain, M. (1990). The Social Construction of National Identity in Highland Ecuador. Anthropological Quarterly, 63(1), 43-59. https://doi.org/10.2307/3317959.

De la Cadena, M. (1995). Women are More Indian: Ethnicity and Gender in a Community Near Cuzco. In B. Larson; O. Harris and E. Tandeter (eds.), Ethnicity, Markets, and Migration in the Andes: At the Crossroads of History and Anthropology. Duke University Press.

De la Cadena, M. (2004). Indígenas mestizos: Raza y cultura en el Cusco. Instituto de Estudios Peruanos.

Duffy, L.N., Kline, C.S., Mowatt, R.A. and Chancellor, H.C. (2015). Women in Tourism: Shifting Gender Ideology in the DR. Annals of Tourism Research, 52, 72-86. https://doi. org/10.1016/j.annals.2015.02.017.

Fajardo, R.Y. (2002). Peru: Pluralist Constitution, Monist Judiciary-A Post-Reform Assessment. In R. Sieder (ed.), Multiculturalism in Latin America: Indigenous Rights, Diversity and Democracy. Palgrave Macmillan.

Femenías, B. (2005). Gender and the Boundaries of Dress in Contemporary Peru. University of Texas Press.

Franco, S. (2007). Poverty in Peru: A Comparison of Different Approaches. In F. Stewart; R. Saith y B. Harriss-White (eds.), Defining Poverty in the Developing World. Palgrave Macmillan.

Fusco, A. (2007). La pauvreté: Un concept multidimensionnel. L'Harmattan.

Gajardo, A., Carrarini, G., Marin, J. and Dasen, P. (2008). Enjeux et défis de l'éducation interculturelle bilingue (EIB) en Amérique latine. In S. Hanhart; A. Gorga; M.-A. Broyon and T. Ogay Barka (eds.), De la comparaison en éducation: Hommage à Soledad Perez. L'Harmattan.

Garcia, P. (2015). In the Name of the Tourist: Landscape, Heritage, and Social Change in Chinchero, Peru. PhD thesis, St. Andrews, University of St. Andrews. https://research-repository. st-andrews.ac.uk/handle/10023/7793.

Gascón, J. (2005). Gringos como en sueños: Diferenciación y conflicto campesinos en los Andes peruanos ante el desarrollo del turismo. Instituto de Estudios Peruanos.

Gill, L. (1993). "Proper Women” and City Pleasures: Gender, Class, and Contested Meanings in La Paz. American Ethnologist, 20(1), 72-88. 
Gonzales Salazar, L.G. (2017). Tejiendo el turismo: Análisis del mercado textil para el turismo en el Centro poblado de Chinchero. Master thesis, Lima, Pontificia Universidad Católica del Perú. http://tesis.pucp.edu.pe/repositorio/handle/20.500.12404/8486.

Henrici, J. (2002). “Calling to the Money”: Gender and Tourism in Peru. In: M.B. Swain and J.H. Momsen (eds.), Gender/tourism/fun(?). Cognizant Communication Corporation.

Herrera, J. (2002). La pobreza en el Perú 2001: Una vision departamental. Economía y Sociedad, 47, 7-14.

Hutchings, K., Moyle, C., Chai, A., Garofano, N. and Moore, S. (2020). Segregation of Women in Tourism Employment in the APEC Region. Tourism Management Perspectives, 34, 100655. https://doi.org/10.1016/j.tmp.2020.100655.

INEI. (2017). Perú: Brechas de género 2017. Avances hacia la igualdad de mujeres y hombres. Lima: INEI, Instituto Nacional de Estadística e Informática (INEI). https://www.inei.gob.pe/ media/MenuRecursivo/publicaciones_digitales/Est/Lib1444/libro.pdf.

Knight, D.W. \& Cottrell, S.P. (2016). Evaluating Tourism-linked Empowerment in Cuzco, Peru. Annals of Tourism Research, 56, 32-47. https://doi.org/10.1016/j.annals.2015.11.007.

Kousis, M. (1989). Tourism and the Family in a Rural Cretan Community. Annals of Tourism Research, 16(3), 318-332. https://doi.org/10.1016/0160-7383(89)90047-9.

Labrousse, A. (1985). Le Réveil indien en Amérique andine. P.-M. Favre.

Lyon, S. (2013). Textiles, Tourism, and the Weaving of Indigenous Identity in an Andean Town. Bacherlor's dissertation, Williamstown, Williams College.

Meentzen, A. (2007). Relaciones de género, poder e identidad femenina en cambio: El orden social de los aymaras rurales peruanos desde la perspectiva femenina. Centro Bartolomé de las Casas.

Meisch, L.A. (2009). Tourism, the State and the Marketing of Traditional Andean Artesanías: Problematic Encounters, Pitfalls, and Competing Interests. In J.M. Baud and A. Ypeij, Cultural Tourism in Latin America: The Politics of Space and Imagery. Brill.

Movono, A. and Dahles, H. (2017). Female Empowerment and Tourism: A Focus on Businesses in a Fijian Village. Asia Pacific Journal of Tourism Research, 22(6), 681-692. https://doi. org/10.1080/10941665.2017.1308397.

Pérez Galán, B. (2012). Retóricas de turismo y desarrollo en los Andes. La red de Turismo Rural Comunitario Pacha Paqareq, Perú. In R.H. Asensio and B. Pérez Galán (eds.), ¿El turismo es cosa de pobres? Patrimonio cultural, pueblos indígenas y nuevas formas de turismo en América Latina. Pasos. http://www.pasosonline.org/Publicados/pasosoedita/PSEdita8.pdf.

Pérez Galán, B. and Fuller, N. (2015). Turismo rural comunitario, género y desarrollo en comunidades campesinas e indígenas del sur del Perú. Quaderns de l'Institut Català d'Antropologia: Etnografies contemporànies de l'Amèrica Indigena, 31, 95-120.

Poole, D. (1997). Vision, Race, and Modernity: A Visual Economy of the Andean Image World. Princeton University Press.

Pritchard, A. and Morgan, N.J. (2000). Privileging the Male Gaze: Gendered Tourism Landscapes. Annals of Tourism Research, 27(4), 884-905. https://doi.org/10.1016/S0160-7383(99)00113-9.

Pumallica, Z. (2016). Inter-aprendizaje campesino. In Centro Bartolomé de las Casas (ed.), Dilemas de la gobernabilidad en el sur andino al 2021 (pp. 181-182). Centro Bartolomé de las Casas.

Scheyvens, R. (1999). Ecotourism and the Empowerment of Local Communities. Tourism Management, 20(2), 245-249. https://doi.org/10.1016/S0261-5177(98)00069-7. 
Scheyvens, R. \& Russell, M. (2012). Tourism and poverty alleviation in Fiji: Comparing the impacts of small- and large-scale tourism enterprises. Journal of Sustainable Tourism, 20(3), 417-436. https://doi.org/10.1080/09669582.2011.629049.

Steckbauer, S.M. (2000). Perú, ¿educación bilingüe en un país plurilingue? Vervuert; Iberoamericana.

Stewart, F., Saith, R. and Harriss-White, B. (eds.) (2007). Defining poverty in the developing world. Palgrave Macmillan.

Terry, C. (2009). Le textile andin à l'heure du tourisme: Continuité, renouvellement et enjeux économiques et culturels. Le cas de la 'renaissance textile' dans la communauté quechua de Chawaytire. Master thesis, Lausanne, Université de Lausanne.

Terry, C. (2011). Tourisme et réduction de la pauvreté: Études des impacts socio-économiques de l'agro-écotourisme du Parque de la Papa (Cusco-Pérou). Master thesis, Geneva, Graduate Institute of International and Development Studies.

Terry, C. (2016). Por una antropología del turismo en el Cusco: Perspectivas y pertinencia. Estudio de cambios e impactos del turismo. Tinkuy. Centro de Estudios Andinos Cusco, (39), 265-297.

Terry, C. (2017). Turismo Rural Comunitario: ¿̨una alternativa para las comunidades andinas? El caso del agro-ecoturismo del Parque de la Papa (Cusco, Perú). PASOS. Revista de Turismo y Patrimonio Cultural, (18), 139-159. http://www.pasosonline.org/Publicados/pasosoedita/ PSEdita18.pdf.

Terry, C. (2019). Tisser la valeur au quotidien. Une cartographie de l'interaction entre humains et textiles andins dans la région de Cusco à l'heure du tourisme du XXIe siècle. PhD thesis, Lausanne, Université de Lausanne. https://serval.unil.ch/notice/serval:BIB_61191E671028.

Terry, C. (2020a). Desvestirse de los imaginarios, repensar América andina: Una etnografía de los trajes típicos en los Andes (Cusco, Perú). La Revista, (80), 39-52. https://www.sag-ssa.ch/ index.php/fr-fr/bulletin-ssa-la-revista/bssa-80-2020.

Terry, C. (2020b). Weaving social change(s) or changes of weaving? The ethnographic study of Andean textiles in Cusco and Bolivia. Artl@s Bulletin, 9(1), 68-89. https://docs.lib.purdue. edu/artlas/vol9/iss1/6/.

Thénard, C. (2006). L'éducation bilingue interculturelle au Pérou: Un rendez-vous manqué? Le cas de l'EBI dans la zone andine quechua. Thesis, Diplôme d'Etudes Approfondies en Etudes du Développement, Geneva, Université de Genève.

Thorp, R. and Paredes, M. (2010). Ethnicity and the Persistence of Inequality-The Case of Peru. Palgrave Macmillan.

Voirol, J. (2016). Faire la fête à Otavalo. Des pratiques ludiques et d'échange à la mise en scène de la culture dans les Andes équatoriennes. PhD thesis, Lausanne, Université de Lausanne.

Weismantel, M. (2005). Afterword: Andean Identities: Multiplicities, Socialities, Materialities. In A. Canessa (ed.), Natives Making Nation. University of Arizona Press.

Ypeij, A. and Zoomers, A. (eds.). (2006). La ruta andina: Turismo y desarrollo sostenible en Perú y Bolivia. Abya-Yala.

Wong, K.-F. (2003). Empowerment as a Panacea for Poverty-Old Wine in New Bottles? Reflections on the World Bank's Conception of Power. Progress in Development Studies, 3(4), 307-322. https://doi.org/10.1191/1464993403ps067oa. 
YpeiJ, A. (2012). The Intersection of Gender and Ethnic Identities in the Cuzco-Machu Picchu Tourism Industry: Sácamefotos, Tour Guides, and Women Weavers. Latin American Perspectives, 39(6), 17-35. https://doi.org/10.1177/0094582X12454591.

YPeij, A. (2013). Cholos, incas y fusionistas: El nuevo Perú y la globalización de lo andino. European Review of Latin American and Caribbean Studies, 94, 67-82.

Ypeij, A. and Zorn, E. (2007). Taquile: A Peruvian Tourist Island Struggling for Control. European Review of Latin American and Caribbean Studies, 82, 119-128. https://doi.org/10.18352/ erlacs.9643.

Zelizer, Viviana A. (2000): A gendered division of labor, Economic Sociology: European Electronic Newsletter, ISSN 1871-3351, Max Planck Institute for the Study of Societies, Cologne, 1(3), 2-5. http://hdl.handle.net/10419/155299.

Zorn, E. (2004). Weaving a future: Tourism, cloth \& culture on an Andean island. University of Iowa Press. 
